\title{
Eager for but Fearful of Communication
}

\author{
Ting Song and Liting Mo
}

\section{Interview with Ms. Y's Mother}

Y, female, born in 1997. Has an elder sister. Grade II intellectual disability. Graduated from a special education school—Shanghai Primary Vocational and Technical School of Changning District. Started working at Shanghai Papa John's in 2015.

Interviewee: Y's mother

Interviewers and writers: Ting Song and Liting Mo

Interview date: July 19, 2016 and January 25, 2018

Interview place: Xingkong Café in Guanghua Building, Fudan University, and telephone interview

\section{A Precious Baby Long Overdue}

Q: Do you mind if we ask when you were born?

Y's mother: November 21, 1959.

Q: How did you meet Y's dad?

Y's mother: I used to live in the old public housing, a stone building with no flushable toilets. My parents moved there in the 1950s and I was born there. We lived on the second floor with a neighbor across the hallway. My husband was the co-worker of the youngest son of that neighbor, so he introduced him to me. We are about the same age. We both graduated in 1977 and I am several months older than

T. Song $(\bowtie)$

Fudan University, 220 Handan Ro., Shanghai 200433, China

L. Mo

Shanghai Normal University, 100 Guilin Ro., Shanghai 200233, China

(C) The Author(s) 2020

W. P. Alford et al. (eds.), An Oral History of the Special Olympics

in China Volume 3, Economy and Social Inclusion,

https://doi.org/10.1007/978-981-15-5005-8_13 
he is. After he was discharged from the military, he got a job working in electronics at a factory, and I worked at a textile factory-we just stayed together.

Q: How old were you when you met him?

Y's mother: I was around 28, and I got married at 30.

Q: Was it considered late?

Y's mother: Almost everyone married late and had kids late back then. The legal age for marriage was 25 , but a lot of people waited till they were 26 or 27 . We were living far from each other and transportation was not as convenient as it is now, so we only got together once a week. We married in February 1988 and settled down in Changning District after that.

I missed my period the second month after getting married, because I got pregnant. But I had a miscarriage when I was a little over 70 days pregnant and I bled a lot. I didn't go out of my way to try again following that. Then 4 years later, in 1992, I adopted a newborn who is now my elder daughter. So, we had been raising my adopted daughter for 6 years before I got pregnant suddenly, but I had a miscarriage 40 days later. I got pregnant again soon after, and that was Y.

In 1997, even though I was past the prime age for childbearing, I didn't get a thorough physical. Had it been today, I would have had my amniotic fluid tested to see if the baby had Down syndrome. I skipped all of that. Y was moving around in my tummy the whole time, without a moment's rest. My own mom passed away when I was very young, so there was no one to advise me on pregnancy. I was working in communications then and had to commute to work every day on an electric bike. No one could tell I was pregnant even in my fifth month, and I didn't take maternity leave till I was 8 months along. One day I felt sick. I was feverish and throwing up, so I went to the hospital myself. The doctor kept me for observation but couldn't find anything wrong. I asked for a C-section before the due date. I hadn't bothered with prenatal nutritional supplements or education, and at 38, I was old for an expecting mom.

Y weighed in at a little over $6 \mathrm{lb}$. She was a beautiful baby, with fair skin and curly hair. The doctor was pushing for breastfeeding, but I didn't have much milk myself, so I fed her formula, and she didn't like it and didn't drink a lot. She would smile at people and play with them, and she seemed to recognize people. She would make loud noises too and cry non-stop. Maybe something was wrong with her mentally as far back as then, but we never even considered that possibility.

She learned to walk first, maybe when she was 14 months old, I don't quite remember. But she learned to speak very late, much later than other kids. We both worked to support the family. I actually went back to work after just 1 month's maternity leave. Unlike some other families with grandparents, it was only the two of us taking care of two kids. So Y was sent to the nursery when she was 10 months old.

Q: Who took care of her for the 8 or 9 months before that?

Y's mother: We paid a lady in the neighborhood to take care of her.

Even after she started preschool, she would still cry a lot and cry really loud. But one thing she understood very clearly was if someone mistreated or hit her, she would come home and tell us about it. One time she said that the teacher spanked 
her, and I figured that it was because she had relieved herself in her pants. She was five at the time.

Q: Did you object to the preschool teacher spanking her?

Y's mother: I did. I talked to the principal and the teacher reacted strongly. I felt that she started holding a grudge against me after that, so I switched Y to another preschool. Some teachers didn't like my switching schools, because they believed that teachers spanked kids almost as a joke. But I disagreed. My child may not have a high IQ, but her EQ is of a decent level, and I simply cannot ignore problems she reports to me. But of course, as long as you leave your kid in the hands of someone else, things will happen sooner or later...

We hopped from one preschool to another, one of the reasons being that the teachers were always saying negative things about my child, and I wasn't happy about that. Another reason was that, as you know, school education is very fastpaced, and when my child, who has a low IQ to start with, couldn't keep up, the teachers blamed it on the lack of education and lack of a sense of responsibility on the parents' part. At that time, we didn't know that there was something wrong with Y.

We would drop them off at school in a hurry before going to work, and pick them up in a hurry and bring them home and cook for them, so we had little time to communicate with them. It wasn't till Y was about to graduate from preschool that a teacher said to me, "Have you taken your daughter to see any doctors? She can't keep up with other kids and as parents, don't you care?" I was thinking that the teacher was being too demanding and prejudiced against my child, and that she must only like outstanding kids. I was already in my forties and suffering from rheumatoid arthritis myself, and I had to work hard to help support the family, so I wasn't paying much attention to Y. Later I told Y that I felt sorry about it, and she said it was okay. She has a low IQ and couldn't keep up at school, but there's nothing wrong with her EQ. Kids wouldn't play with her, so she asked me to buy stickers and little toys to share with them. And whenever she was bullied at school, she would come home and tell me about it. She wouldn't talk at school at all.

\section{Difficulties in Learning at Regular School}

\section{Q: How did she do at elementary school?}

Y's mother: She started elementary school at eight, but her IQ was that of a 2- or 3-year-old, so how could she keep up? Her dad was very patient at helping her with homework, and she was okay with calligraphy. But she couldn't use her brain, and her dad had to do all the math including additions and subtractions for her.

Q: Would any classmates bully her?

Y's mother: She had bad grades, so no one would play with her. They would grab her pencils and erasers, so she spent the first year crying.

Her Chinese teacher suggested that I take her to see a doctor. Back then, kids like her were tested at mental institutions. I took her to several of them and she was tested 
on shapes like triangles and diamonds and on addition and subtraction, and she was clueless, so the test results were disheartening.

One day she saw me crying in the hospital yard, with a sheet of paper in my hand. She asked if she had tested poorly and I confirmed it (sobbing), telling her that her scores were all bad. She said, "Don't tell Dad, otherwise he will be mad." She was only seven or eight then, but she understood.

Q: Why didn't she want you to tell her dad?

Because I was the one raising her. When she was young, I would go to work during the day and pick her up at 3 or 4 p.m., and that was the way in preschool too. Even now, she interacts more with me. She isn't expressive. Her dad doesn't talk much with her. He just helped her with homework and it was very hard for him, and towards the end, it was basically her dad doing all the homework for her. But there was nothing we could do about it.

(Crying) So, we just resigned ourselves to it and left the regular elementary school. Actually, after completing first grade, she hardly attended second grade because she just couldn't keep up. We visited Qixing Special Education School in Putuo District. The director of academics asked if we had made a mistake because Y looked fine. I showed him the test results and he immediately accepted her. That happened during summer vacation, and Y started at that school on September 1.

\section{Thriving at Special Education School}

Q: Which grade was she enrolled in at the special education school?

Y's mother: Kids were enrolled by age, so she went straight to third grade.

Q: What did she learn at the special education school? Was the curriculum the same as at regular schools?

Y's mother: How could it have been the same? The curriculum was very simple, and parents sat in on almost all of the tests. The school offered pottery classes using clay, and she won some prizes. She was sent out to competitions and sang Grateful Hearts and Invisible Wings. She had a lot of opportunities to interact with the world outside school. She participated in all of the activities at school, and the school took very good care of her and offered her a lot of opportunities. She was chosen to raise the flag every day, and to sing and dance. She even performed at Special Olympics.

Q: When did she participate in Special Olympics?

Y's mother: She was still in elementary school. It was a big deal at the time, with interviews by the TV station and tapings, which I've put somewhere. She used to be skinny and looked okay, whereas a lot of other kids at the school looked very offish. Last time I even put the video on DVD and told her teacher about it. Which reminds me, her teacher has a lot of pictures of her raising the flag and dancing, and she knows very well which activities she has participated in. The teacher is super nice. She took over the class when she was in her twenties, and now she is probably 33 or 34 . I can't recall all of the activities.

Q: Which event did she compete in at Special Olympics? 
Y's mother: Hula hoop.

Q: Where did she learn that?

Y's mother: At school, since she never did it at home and I have no idea how many twirls she could do. She also competed in diabolo and cucurbit. I'm not $100 \%$ sure, actually. She wished she could be better like other kids, saying that the teacher gave her so many opportunities, but she was not the best, and she would tell me who could do this and who could do that. I told her that there were certain things she could do and certain things she couldn't and that she had to accept it.

$\mathrm{Q}$ : Did she enjoy participating in those activities?

Y's mother: She did. She really wanted to participate and to be on camera, but she wouldn't ask her teacher for it. She would rather wait for the teacher to ask her if she was interested in a certain activity. She cared a lot about the teacher acknowledging her and giving her special attention. She has a strong sense of honor and a grateful heart.

Q: Was she happy at school?

Y's mother: She loved going to school and being with her classmates. But she hated studying and homework. Her grades were awful and she had no math concepts. She is better at addition and subtraction now, but still can't do multiplication and division. She always wanted to go to school because she could have fun there.

Q: How did she get along with her classmates?

Y's mother: All of her classmates had disabilities. They only knew that the teacher liked Y but didn't know how nice Y is. Some parents knew and would comment on how nice she is.

One thing good about her is that she is eager to help. There were all kinds of kids at the special education school, and in the same class, you could find kids who couldn't control their bowel movements, who had Down syndrome, and who had severe autism. Y was lucky in that she was assigned to a class with the healthiest kids. At least that's what it looked like since there were no kids in the class with really severe conditions like cerebral palsy. She would help feed the classmates. And when some kids relieved themselves in their pants, she would help the teacher fetch the cleaning lady. So, the teacher was very nice to her.

Q: Were there any classmates she was close to?

Y's mother: The kids wouldn't play with her, so she asked me to buy stickers to share with them. She was very eager to make friends, but the kids still wouldn't play with her. She would come home and tell me about it, and I could empathize.

There are two classmates from elementary school that she still meets with, and their disabilities are not as bad as hers.

One of them is very expressive and watches a lot of TV shows, but she can't tell the time on a watch.

The other one is really into dancing. She is very pretty and can't tell the time on a watch, either. She lives with her grandma, her dad and her uncle. Her dad is mute and her uncle is mute, blind, and deaf. She was adopted, so her family situation is very sad. Her aunt has been taking care of the family. She was on the school dance team and tried very hard at dancing and calligraphy. She likes to go on dates and often hangs out with boys. 
Both of them graduated and neither of them has a job. One goes to the Sunshine Home, and the other is waiting for her aunt to decide whether to send her there.

Q: How did she get along with the teacher?

Y's mother: The teacher was very nice to her. She was able to go out for competitions and win awards because of the teacher, and the teacher would give her a bigger portion whenever she distributed goodies because she wanted to encourage her. $\mathrm{Y}$ had a lot of certificates of honor. She performed at Changning District Cultural Club and presented flowers at activities hosted by the Disabled Persons' Federation (DPF) branches. So, I often tell her that she should be contented. Wherever she went for school, the teachers valued her. And I gradually realized that she isn't expressive by nature, but through her actions, you can feel that she is being nice to you because you have been nice to her.

She is slightly autistic and doesn't talk. She would answer whatever questions the teachers asked her, but if she ran into the teachers somewhere, she would have nothing to say to them. Riding with me on my electric bike, she couldn't stop chatting to me. And she understood everything including which teacher was nice and what the teachers said. Sometimes she would have a sense of loss, saying, "The teacher is getting married and having kids, so she won't like us anymore." She has no sense of security and doesn't believe that other people will always treat her nice.

I actually interacted a lot with the teacher. The teacher would often take them out to eat. I wouldn't shortchange the teacher because everyone should be appreciative. Now that Y has graduated and the teacher has a kid and even the teacher from the vocational school is pregnant, we don't contact each other as often. Some of her classmates know the right things to say, like "I should buy something and visit the teacher" or "I should call the teacher." Y doesn't say things like that, and even though she will have similar thoughts, she won't make the call. She will wonder why the teacher doesn't take her out anymore, and I will tell her that everyone has their own life and we should try not to bother other people, and that she can buy something and visit the teacher instead of waiting for the teacher to contact her first. That's the way we are. We do what we are supposed to do in whatever positions we find ourselves, and our appreciation should not be short-lived. If you think of your teacher, you can show it by sending a card or buying a bouquet of flowers.

Q: How long did she stay at the special education school?

Y's mother: She went to Shicun Elementary School in Changning District for a little over 12 months, then went straight to third grade at Qixing School in Putuo District, which means that she had 6 years' elementary school. With the 3 years at Changning Primary Vocational School, she has had a total of 9 years' schooling.

\section{A Scholarship Recipient at Vocational School}

Q: What did she learn at the vocational school?

Y's mother: She learnt making pastries and room service, and received certificates for both. The work was all about using her hands. The teacher would distribute flour 
and the students would make dough and bake and bring the baked pastries home. She also learnt to fold clothes and bedding, pour and deliver tea, place chopsticks, teacups and towels, and place placards for arriving customers. She spent 2 years learning and did an internship the third year.

Q: What kind of pastries did she make? Would she make any at home?

Y's mother: She made Western-style pastries. We kept a diary on when she practiced at home what she had learnt at school on certain days. She would roll the dough with a pin before frying it.

Q: Did she like making them?

Y's mother: In the eyes of the teacher, she was the best listener and had good organization. She liked what she did and was able to not make a mess.

Q: Did she like learning about room service?

Y's mother: She did, but she had bad balance, so she often broke the teacups when carrying them.

Q: Was the 2 years' curriculum at the vocational school easier or more difficult than that at the special education school?

Y's mother: The classes she was in at the two schools were of different levels. At the vocational school, she was among the better students. Students at the vocational school were all average kids ${ }^{1}$ with good brains. The teachers knew that they were not into academics and therefore had no unrealistic requirements of them. Some of the tests were especially designed for them and were different from tests for regular students. It's almost like special education.

One of the teachers kept asking me to have $\mathrm{Y}$ take the entrance exam to secondary technical schools. I told him that Y wasn't made for it, and he said I shouldn't underestimate her. I couldn't argue with him, so I had to tell him that Y has a disability certificate and Grade II intellectual disability. He even doubted the authenticity of the certificate. I am not kidding.

While she was preparing for the secondary technical school entrance exam, I panicked and felt enormous pressure. I couldn't sleep and would get up a little after four in the morning. I had no energy, so I had to drink two cans of Red Bull before waking her up at 5 a.m. I also borrowed a friend's study materials and had them copied for her. They came in such a big stack, (gesturing with her hands).

That teacher kept saying to her in class, "You are not studying hard. Do you not study at home?" He treated her as the average kid and said the same things to her every day. She would cry and come home and tell me about it. But what could I have done?

"Why isn't she studying? She can do it." No matter how I explained to him that my daughter couldn't do it, he refused to understand. In the end, I had to show him the disability certificate and he treated it almost as an antique. I told him I wasn't kidding him, because all parents want their kids to do well at academics. I had to make him understand that my kid couldn't pass the exam, so he shouldn't force her to

\footnotetext{
${ }^{1}$ Shanghai Primary Vocational and Technical School of Changning District is actually a special education school providing students with ID with vocational training.
} 
take it. She couldn't comprehend any of the test materials, so how could she achieve the unrealistic?

I said, "The truth is that my daughter is half a step behind other kids. She did try, but that's the way it is. I can't force her to take any entrance exams, because I shouldn't obsess with it. If she had it in her, of course I would let her pursue higher education. It's not as if I couldn't afford it." I got along very well with her homeroom teacher, but not with that other teacher. But of course I shouldn't accuse him of anything.

Q: The teacher who encouraged her to take the secondary technical school entrance exam, was he from the vocational school?

Y's mother: He was from Changning Primary Vocational School. He didn't know about our situation, so he would accuse us in front of everyone of not being responsible. Y couldn't memorize her study materials and would cry every day.

At Changning Primary Vocational School, Y even received a scholarship of 300

yuan. The teacher said nice things about her.

Q: Can you tell us more about the scholarship?

Y's mother: She should have got the scholarship for 2 years. The first year, she received the 300 yuan. The second year, my understanding with the teacher was that she would receive it, too. But because that other teacher asked her to take the secondary technical school entrance exam and she couldn't memorize the materials, everyone just pretended to forget about the scholarship, and I didn't pursue it. If the school believed that she wasn't trying hard at academics, I didn't want to fight over it. The scholarship was recognition of her dedication to schoolwork, and the school must have had its own reasons for withholding it.

During the third year at the primary vocational school, the teacher referred her to an internship at Papa John's and referred her good friend, too, the one whose dad is mute. Y was sent to the Papa John's store closest to where we lived, and I could get there within 20 min on my electric bike. The other girl was sent to Minhang District, but she lived in Putuo District, so she had to walk a long way to the store after getting off the subway. She didn't want to go anymore after just 1 day at the store.

Before the one-year internship was up, Papa John's called asking us to bring over the graduation certificate so that it could sign a contract with Y. So, when the time came, I picked up the graduation certificate and Papa John's signed a 3-year contract with her.

\section{Adapting to a Demanding Job}

Y's mother: Don't tell anyone this, but when my daughter first started the internship, the mentor was very strict, and Y would cry her eyes out as soon as she got home. She grew up in a protective bubble. We spoiled her and never yelled at her or spanked her. That's how my elder daughter grew up, too. Then other people came along and were strict with Y, but she is not the average kid, she has a disability certificate! 
I was very frustrated and wanted to give up. I am very strong-willed myself and can't stand any wrong being done to my kids. But I told her, "Let's find out where you can improve. It's true that your mentor is strict with you about work, but she doesn't know you well."

One time her mentor came out of the store and told me, "I treat her as my own daughter, which is why I am very strict with her." She was indeed the kind of person to expect a lot from those working for her. So, I could only tell her that I was leaving my kid in her capable hands. Then I took her hand and Y's hand and put them on top of each other and asked her to take $\mathrm{Y}$ inside the store.

There were two choices. Either I asked Y to get back inside the store, or I took her away with me. I thought it through and decided to have her stay at the store.

Some kids may have been spoiled at home and therefore cannot hear anything negative said about them. Y wanted to unload on me thinking that I might fight her battle for her. Yes, sometimes I do fight her battles for her. But I struggled over this one. She has a disability, so where can she get a job? I didn't think anyone would listen to me if I wanted to plead for a job for her.

I heard that someone was fired at the store, so I asked Y if she understood the implications and I told her not to say anything if she did. Her mentor had multiple roles to play at work, and she must have her own strengths to have become the aggressive lady that she is. We can actually learn something from her there. She has experienced a lot which we know little about, and she needs to let it out, and there are a number of ways she can do that. I said to Y, "You work hard, mopping the floor and wiping the tables, but those are your job responsibilities and you can't be picky about them. Why did Papa John's call you? Papa John's was careful about which of the interns could do the job and could therefore stay. It's not hiring anymore, so you should feel lucky that it called you to sign the contract with you. Some things you just need to understand but not say out loud." So, she promised not to say anything and of course I wouldn't say anything either. With some people, when they did something wrong and you say they did it right, they won't say anything about you, but if you point out that they did wrong, then you will end up paying for it.

When she first started working, she would cry non-stop every night she got home. She is much better now. She works in the kitchen, making pizzas most of the time. Based on the orders on the display board, she will make the dough, add ingredients, and bake the pizzas. It takes a lot of strength to knead the dough for a 10-inch-plus pizza, and she is short. Sometimes four people or three people carry the workload of five people, and each person has to do multiple technical jobs. The technical part should be no problem for regular employees, such as baking chicken wings, boiling noodles, and making drinks. When there are not as many customers in the afternoon, employees are required to check the expiration dates of the food and remove what is about to expire, to wipe down the fridges, to mop the floor, and to do some washing. She lives a full life every day (See Fig. 1).

I told her to learn at every job position because it would be good for her. She shouldn't complain about the work being tough, and there's no other option anyway. She could have sat at home enjoying the A/C and the computer, because she is only 20 this year, but then she would have learnt nothing and as she gets older, she will 


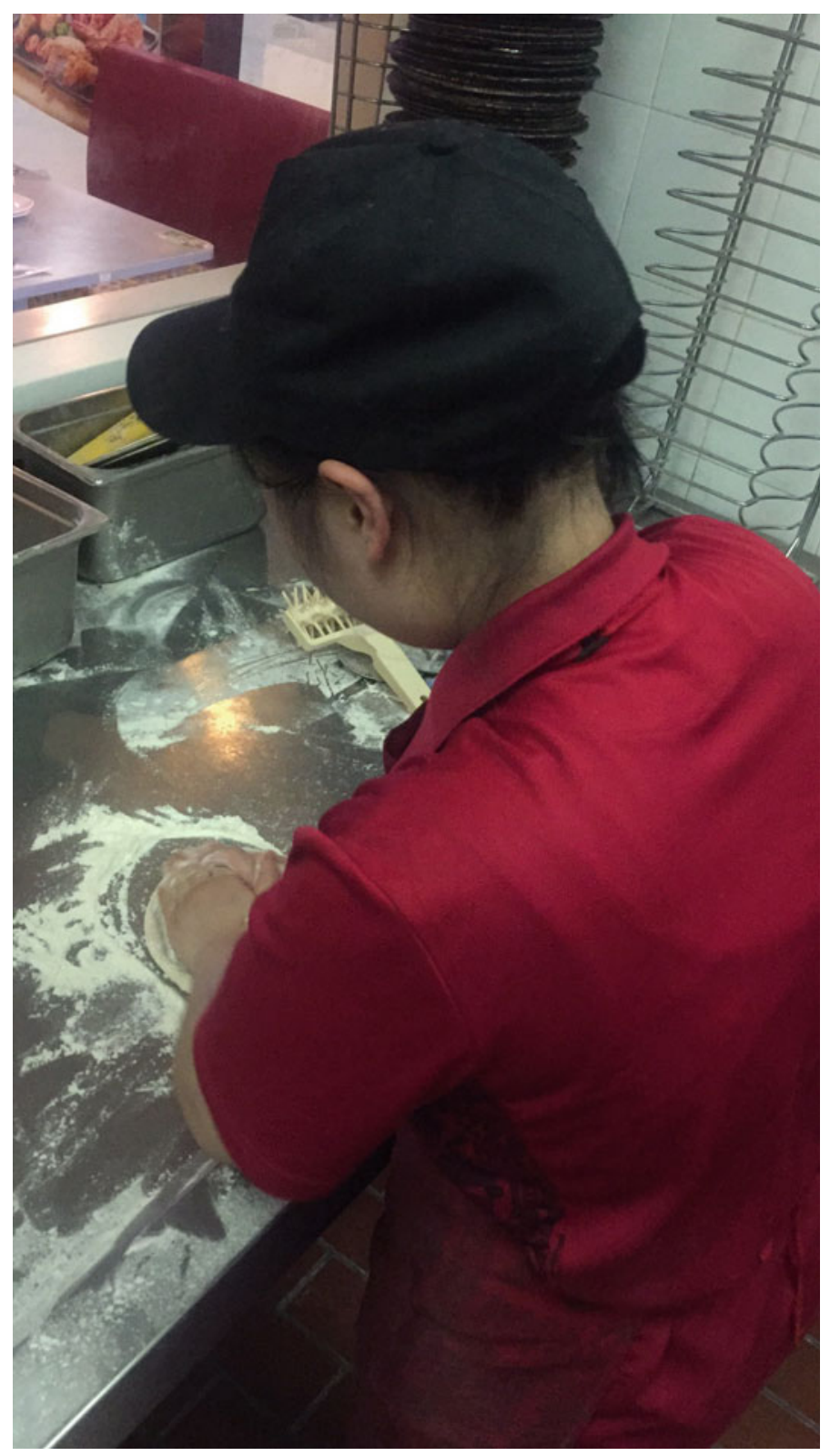

Fig. 1 Ms. Y at work 
end up with nothing. So, she should step in wherever the store needs someone, and her efforts won't go unnoticed. And it won't be for the pay, because she won't get much of a pay rise no matter what. The minimum pay used to be 2,002 yuan. It has since increased to 2,190 yuan and the take-home pay is 2,250 yuan with 60 yuan being some kind of subsidy. She might get a very small raise next year.

Q: So, Y would cry about her work and whine to you when she got home, but she has stuck with it.

Y's mother: What choices does she have? Could she have quit? She struggled in April or May of this year, because she was about to sign the contract. The teacher from the special education school had kept in contact with her, and the teacher from the vocational school visited her often at the store to collect feedback on her from her mentor and manager. She had pressure and felt that by signing the contract, she would sign herself over to Papa John's.

I told her it's okay and that it's just a job and an honor that she has been given the job. I happened to eat with the aunt of one of her classmates. I forgot where that girl was working except that it was a tough job requiring her to wash fish heads on freezing days. She had never worked before that and her hands had been soft and tender. So, the aunt told me not to let Y give up the Papa John's job. Her mom has three kids and she is the only healthy one. The two sons became deaf and mute and half blind in their thirties. To help her kids, her mom found the oldest son a wife, who is a mute from Zhejiang Province, and helped them adopt a child. That child was Y's classmate. She is very pretty but was having a hard time.

Every day Y gets up, I will remind her to get ready fast and not to be late, because the mentor will be mad if she gets to work late.

Q: So, Y's reactions are faster now, are they?

Y's mother: They are, even though it took a while. The manager even asked if she wanted to work in the dining area. I am always reminding her, "Make sure you refill the tea. And don't you use a lot of ingredients for the pizzas like tomato and red pepper! Check that there's enough of everything on the counters and refill immediately when there's the need, instead of having the mentor scream at you, 'YY, YY, we are out on this!' or having her get all impatient and say, 'YY, hurry up, what's taking you so long!' The first few days that she worked there, she would come home and cry her eyes out. Now the mentor treats her better and often shares this or that with her. And the manager is always saying good things about her. It will not be so easy for the store to hire another employee being cared for, especially considering the mentor's temper and impatience when someone is just one step slower. If the store was to let Y go, it might end up with someone who wouldn't listen and couldn't understand. Kids like Y do understand to a certain degree, so they can still survive in society one way or another.

Q: Does she work every day, or does she have days off?

Y's mother: She does have days off, per government policy. She works 5 days a week and has Thursday and Sunday off, and she normally works from 11 a.m. to 8 p.m.

Q: How does she get along with her co-workers? 
Y's mother: She has nothing to say to them. They are all from outside Shanghai and older than she is. Sometimes they will say to her, "Y, why aren't you talking to us? It's no fun when you don't utter a single word the whole day." She takes after her dad in that she isn't talkative. When asked how she is doing, she will just say, "Not too bad." She will talk to me when she comes home, but she doesn't talk to her co-workers.

Q: Is it because she doesn't feel like doing it?

Y's mother: She does want to talk, but she is worried about saying the wrong things. I told her that no one expects a speech from her, and that she could totally handle small talk like, "Have you eaten yet?" I truly believe she is autistic. But the less she talks to people, the more people will gossip behind her back. Of course, I can't see what happens at work, and everything I know I have learnt from her. I keep telling her to approach others to talk, because I have observed her for a long time and concluded that she will never take the initiative to communicate with others.

I often stop by the store, and the mentor always tells me not to worry because $\mathrm{Y}$ is doing very well now, so I will always express my appreciation. One time I dropped off lunch for her and the mentor asked me why I stopped by at such an early hour, so I said I was on some other errand and the store happened to be on my way. I wish Y was more talkative like I am. Now she feels more at ease at the store, but she is still very attached to home. No one gives her pressure at home and everyone is so much more tolerant of her at home. I was told that I spoil her, but I have a special-needs kid-what am I supposed to do but spoil her?

Q: So, she talks mostly just to you?

Y's mother: Yes, to me. Sometimes she wants me to take her to work on my electric bike. You are not supposed to have any passengers on your electric bike, and the police are very strict about that now. Even when I showed the police Y's disability certificate, I was told to take her on public transportation instead. So, Y will sit behind me on the bike and keep whining about this or that, and I will explain things to her very bluntly, and she will feel better. Even when I am ready for bed at night, she will talk to me non-stop.

She likes to repeat herself, which I see as a problem. I keep telling her not to do it because it's not normal, but she never remembers what I tell her. She finds it perfectly normal that there are things she needs to unload and I need to explain to her. For example, if something happens at the store, she will tell me about it more than once. I will tell her, "You already consulted me on that one. Some things you just have to understand but not talk about, and I can't exactly explain it to you because I should not badmouth anyone." Some employees play on their phones, and Y wants to do it, too, but the mentor will scold her for doing that. I told her that's something that cannot be balanced and that she shouldn't struggle with. She can play on her cell phone all she wants at home and Mom and Dad won't say a word, but the workplace has the right to ask her not to do it. What can I do? I can't tell the store not to discipline my daughter, can I?

I tell her that people are watching how hard she works. She was spoiled by a lot of people at school and got the best of everything, but at the workplace, there won't be that many people giving her that many opportunities. She is very understanding, 
really. She has a decent EQ. She observes everything and she can read what's in your eyes.

We live pretty far now, and I don't have much to do except to cook, so I will drop $\mathrm{Y}$ off at the bus station sometimes. She will come home by herself. She is okay going to work and coming home on her own.

When I visited the corporate site of Papa John's, everyone was so courteous towards me, because $\mathrm{Y}$ is kind of famous there. The teacher from the vocational school did us a big favor by getting Y into the Papa John's store close to where we live. Some people commute so far to work, and for people with ID, commuting across several districts to work is too tough. I keep telling Y that she is luckier than some other people and luckier than those staying at the Sunshine Home who can't really talk well and can't even read a clock. She may be a little behind people without disabilities, but she is doing pretty well in her own way. I encourage her every day. As parents, we don't have the right to accuse her of anything wrong with her, because it's our responsibility, not hers. She is innocent.

(Y called. After hanging up the phone, Y's mother found Y's photos and showed them to the interviewers.)

Y's mother: This is her. (Laughing)

Q: How cute!

Y's mother: But she has put on some weight, because she often eats out randomly. She starts work at 11 a.m., takes a break at 2 p.m. to eat the lunch she brings from home, and doesn't get off work till 8 p.m. Normally she has a good lunch at home at noon and has dinner at 5 p.m. But that's not the schedule at the workplace. She will eat at 2 p.m., and how can she not eat anything else between 2 and 8 p.m.? After she gets home at 9:30 p.m., we will fix her something to eat. By the time she finishes her shower, it will be 11 p.m. or midnight. She will then watch some TV and play on her phone in her room. I just want her to enjoy good health, whatever it takes.

Q: Does she buy you gifts every time she gets paid at work?

Y's mother: Not every time. When she got paid the first time, she spent several hundred yuan taking us out to eat. Then she bought two cell phones, one for her and one for her dad, which cost about 3 months' pay. Another example is that when we needed to buy an A/C unit, she offered to pay for it, and when 1 month's pay couldn't cover it, she offered 2 months' pay. My elder daughter will never make such offers. $\mathrm{Y}$ is very caring towards family members and often offers to do things for them. She was constantly worried about her grandpa's health, and would give her grandparents money in red envelopes for Chinese New Year.

Q: What would have been the ideal job for $\mathrm{Y}$ as far as you are concerned?

Y's mother: Papa John's was hiring directly from special education schools, and Y caught the last boat. It must have been the decision of the company or the education bureau and I have no say in that. Y works 5 days a week now with 2 days off, which is normal. But she has no subsidy for meals or transportation, Papa John's doesn't provide free meals, her pay is the minimum and the only extra money she gets is 50 yuan. I am not in a position to talk about an ideal job for her because she doesn't have many skills. I have to recognize that and not have too many demands. Being a mother, I should be appreciative first that the government and the company have 
found a place for Y. But I feel that I can ask for some small things for her like subsidies for meals and transportation, because I would like to keep some hope alive for kids like Y who supposedly have descended "from the stars."

$\mathrm{Q}$ : Did you take Y for any other IQ tests later?

Y's mother: I was advised to, but why would I want to do it since she already got the disability certificate? Should I have got rid of the certificate? I don't see the need. The government is treating her better and better. Without the certificate, can you imagine her interviewing for jobs like people without disabilities? I can't, because she wouldn't be able to say anything at the interview. I was also advised to let go and allow her to be independent. I do want her to be independent, like the way my elder daughter and I are independent and self-sufficient.

\section{A Lonely Girl's Love for Dogs}

Q: What did she like to do when she was young?

Y's mother: She liked stickers. She would peel them off in small pieces and stick them again on paper. Each box cost just 2 yuan, so we bought her a lot. She also liked to dress up and strike poses, because she liked how she looked. And she was so happy having her picture taken. I still have a lot of pictures from when she was young. She was very observant and would notice who hadn't been in contact with me for a long time and which auntie looked very young, and she told me that I would look very young too if I applied makeup.

$\mathrm{Q}$ : Did you take her to the park?

Y's mother: She went to the park with her classmates. She liked playing those claw machines and she grabbed a lot of teddy bears. We also took her to KFC once or twice per month.

Q: Do you still take her out now?

Y's mother: I mentioned a girl with an auntie taking care of her. Y will go out with that girl, to eat and to shop.

Q: Does she like shopping?

Y's mother: She does, and often ends up buying a lot of stuff. She buys makeup because she knows how to use it. She also buys some trinkets sometimes but I will tell her that she can't wear those working in the restaurant industry. I am often amazed at her ability to use up every penny on her card, like more than 1,000 yuan after just one shopping trip.

I won't tell her dad because I don't want him to know. I will try to give her the right guidance instead of being too accusatory or pampering her. If I don't give her enough allowance, she won't be happy. I will tell her that since she has worked for

\footnotetext{
${ }^{2}$ Kids who have descended from the stars: This term refers to autistic kids because they cannot engage in normal communication with the outside world, and just like stars, they are far away from the earth and live in their own world.
} 
the money, she is entitled to be happy and that I won't impose financial restrictions on her. Why? Because she should be allowed to buy whatever she wants.

Q: Does she play on her cell phone?

Y's mother: She had a small computer; now she has a big one. She also has an iPad and cell phone. She gets home late, after 9 and close to 10 p.m. She often plays on her cell phone late at night and I have to remind her that she will have to work the next day so she needs to go to bed early. She uses up data so fast. Five hundred megabytes per month isn't enough for her, and several times she used 500 or 600 yuan for data alone.

I have a family package with several lines, and she has one of the secondary lines. One time I received a bill for 800 yuan. I called 10086 to ask about it and was told that my secondary line used up a lot of data. I said the person with the secondary line has intellectual disability and no idea of data usage and that I had no idea of how much she had used and I couldn't afford the bill. So, the representative reduced my bill by 430 yuan, which was the maximum he could do.

She hadn't really used that much. Being a girl, she likes watching videos when she eats, so she would turn on data and just drain the data while she kept watching videos. So, I kicked her out of the family package. Instead she has a certain amount of data plus 5 yuan extra, and nothing more as soon as she uses that up. She worries about whether she can get Wi-Fi wherever she goes now.

Q: What kind of movies does she like to watch?

Y's mother: New releases. I took her to watch the one starring Yang Ming... what's it called?

Q: Small Era.

Y's mother: Right, Small Era. I wanted her to see how people carry themselves on certain occasions. I will tell her, while trying to be casual about it, that people should aim high instead of looking downwards because there's nothing to see when they look downwards.

Q: Does she watch TV series?

Y's mother: She does. She watches those ones from South Korea as well as the latest hits produced domestically. She likes watching young and good-looking guys. And she has a good memory and can recall which shows the actors have appeared in before. Sometimes even her elder sister will ask her about it and she can immediately provide the answer. It's weird. I've been watching Female Cops and $K 9$ these past few days. I also watch war-related shows, but not a lot of love stories about young people. I follow Guan Xiaotong, and I will ask Y to check whether this actor is married or how old the son is and personal information like that, and she will immediately try to dig up the information for me, because I wouldn't know how to do it.

Q: So she remembers faces well.

Y's mother: Right. Sometimes she will ask her elder sister whether her co-worker who dropped by one time before will come again. She keeps track.

She liked Lu Han for a while. Then she liked the singer Zhang Yuan from the show Happy Voices and spent several hundred yuan voting for her, but that person didn't win and Y cried over it. 
I asked her why she would follow Lu Han and whether she ever hoped to meet him in person. I said, "Fans of people like Lu Han need to have money. Front-row tickets to his concerts cost several thousand yuan, and even if you have that kind of money to spend and even if you get to see him up close and personal, will he know who you are?" We have so many books on him at home (gesturing with her hands), plus pictures. I told her that she's a fan of Lu Han today and will be a fan of Wang Han tomorrow. Since she is moving from one to another so fast, she shouldn't spend so much time or energy following any of them. I nagged a couple of times before she got it, and she stopped following anyone. I never get mad at her because she won't like that. She is approaching 20 now, so she can be rebellious if she wants to. And it's better for her to like someone than not knowing who to like at all.

Q: So she has several classmates, but no friends who are really close. Is that right?

Y's mother: She wants to get close to her classmates but doesn't know how to communicate with them. Unlike you and me. We seem to have clicked today and there's a lot we can talk about. She has nothing to say to other people.

There's this girl who is really nice. She is 1 year older than Y and works at China Eastern Airlines making pastries. The pastries she makes are so pretty. Y wants to hang out with her, but they have nothing to say to each other when they are together. Sometimes several of them will go to a bakery to make cakes or go somewhere else for arts and crafts. I set it up for Y many times. I would call up the other girls asking when they would have time to go out with Y and where they wanted to go, and on Y's birthday, I would invite them to celebrate it with her. She has nothing to say. Actually, she has a lot to say, but just nothing to say to them. There are classmates who are in a worse condition than she is and a couple of them tried to get close to her, but she has a sense of distance with them. She feels that she doesn't like a certain girl because she is always dating. She knows well what is good and what is bad.

She has several classmates from the vocational school who are not exactly reliable. They have a WeChat group and Y always responds warmly to whatever is proposed in the group. When some trip was planned, $Y$ would be hyped up about it. And then it rained and nobody wanted to go out, and when $\mathrm{Y}$ asked, nobody responded. Sometimes she will post in the group, "I have today off. Do you guys want to go anywhere?" And she will never hear from anyone. And if some of them do get together with Y, they will go home after just a little while.

I can't tell if those classmates are normal or not. If you think something is off with them, they behave perfectly normal sometimes. But if you think they are normal, they don't carry through a lot of times. I told Y, "I know you want to hang out with them, because hanging out is fun. But those girls are not people you can hang out with, which means that in some way, they are behind you. You have a sense of time. If they were really your good friends and behaving normal, they would talk to you. So what if it rains? You can still hang out somewhere, not a problem at all! So there's something off with them, not with you." Sometimes if she was about to run late, I would have her take a taxi so as not to keep anyone waiting. Those are minor details, but those classmates are totally clueless. I know that $\mathrm{Y}$ is lonely and wants to be with them. Sometimes she will tell me that she is going to the movies, then she will just buy herself a ticket to Caoyang Movie Theater. 
Q: What does she normally do at home? Is she okay staying home alone?

Y's mother: Absolutely okay. What happens at home is this: she will make her bed after getting up in the morning, wash her face and brush her teeth while I cook for her. When she gets home from work, she will take a shower and get onto the Internet on her phone to watch a TV series while laughing to herself and sometimes humming a song. If we ask her to do the laundry, she will do it, and sometimes she will do the dishes for us. But she won't do anything if we don't ask her. She knows how to cook and does cook occasionally, simple dishes like egg fried rice and potato fries. She has no problem with any of those.

She is very loving. When she was three, she wanted a dog, so I got one for her. The dog died in December 2014 and she cried and was so sad. I told her, "Dogs are like people, except that they live shorter lives. If they live past 10 years, they are the equivalent of 100-year-old people. As long as you have been nice to them, they will always protect you, and it will be like they were still living a healthy and happy life with you." After the dog died, we wrapped it up and called for the pet mortuary people. We drove together to cremate the dog and brought back its ashes to place at home. The total cost was 1,000 yuan and I don't think many families in Shanghai would have done that for a dog. We had another dog that died last year and we spent 1,300 yuan taking care of that one.

Q: Why did she want dogs?

Y's mother: She has always been lonely in her heart ever since she was young, and she is still lonely now. If I go out, she will keep asking me, several times a day, "Are you home yet?" "Are you coming back now?" or "Where did you go?" She is so mild at home. She won't make any sound except to cuddle with and talk to the dog. The dog is happy to be with her and sometimes gets to sleep with her in her bed.

I started with one dog, then had two before having three. Two of the three died and I have one left now. She loves pets. We will often go outside and bring home stray dogs, wash them and fix them up and give them away to good families.

The dog we have right now is already 12, so she is worried and asks me to get another dog. I said having dogs is a lot of work and she has no time. She doesn't get up till 9 a.m., so who will watch, feed and wash the dogs for her? She also likes tigers, but she can't exactly bring one home to keep, can she? She has no such money, so she should be happy just looking at the animals. Bottom line is that she is lonely.

Q: Who normally takes care of the dog?

Y's mother: The three of us. She walks the dog when she gets home at night, I feed the dog, and my elder daughter never helps with anything.

Q: Do you see any dramatic changes in Y from when she was young?

Y's mother: She used to listen so well and never put up any resistance. Now she will show her temper from time to time.

Q: Showing her temper means that she has grown up, right? Exactly what kind of temper does she show?

Y's mother: Several of her classmates would get hysterical when they lose control of their emotions and do whatever they want. $\mathrm{Y}$ is never like that, but she will show impatience in her actions or language. I will say, "How come you are being unstable emotionally?" And she will immediately ask, "Am I being mean to you?" I will ask 
her if she would bring her impatience to work and she will say "No", because at the workplace, hardly anyone will talk to her. It's not that she doesn't want to talk, she just doesn't feel that she has anything to talk to anyone about.

Q: Has she ever shown any clear signs of rebellion?

Y's mother: No, because she dares not. But she will judge a person in a very sensible manner. My husband is my age. Sometimes he will say inappropriate things and Y will call her dad out on that. Sometimes he will joke with me, "What do you do at home all day? You have nothing to occupy you?" The truth is that I do almost everything at home, so I will retort, "I don't do anything? Y, do I do anything?" My husband is 8 months younger than I am. He has not a single mean bone in him, isn't talkative, and is very much an introvert. But sometimes he will say things that I can't take, so of course I will talk back and Y will take my side. He is a nice guy, nonetheless. Last time when we were doing home renovations, Y said, "Mom, don't ask Daddy to do this or that. It will be too much for him."

$\mathrm{Q}$ : You mentioned twice that $\mathrm{Y}$ can judge a person in a very sensible manner. Can you give us an example?

Y's mother: She is a good observer and notices my expressions and that of her dad and elder sister. She also notices the expressions and words of co-workers and schoolteachers. For example, when she was going to the special education school, some teachers behaved differently towards different kids, being especially nice to those with family background or speaking gently to good-looking kids. Y noticed it and wasn't happy about it. I told her, “There's nothing you can do about it. Teachers are not your mom. Mom will be nice to you whatever your looks, whereas teachers will definitely be prejudiced, because there are people who are like that everywhere." She will also notice whether you are in a good mood today or not. I will talk to her sometimes about what happens in society, and if she gets it, it will be helpful to her.

\section{No Forced Marriage and No Plan for Kids}

\section{Q: What are your family's thoughts on marriage for Y?}

Y's mother: People without disabilities will let things happen naturally. They might meet marriage candidates through mutual acquaintances or at work and then get to know them better. No one in the family has tried to set $\mathrm{Y}$ up on any date. I have been super busy recently. I took my in-laws out of the nursing home and had been taking care of them. But they were too sick and passed away eventually.

My main concerns are: First, as parents, we hope that Y can get married (sobbing), but it will take longer and be more difficult for her, than for people without disabilities, to get to know someone. She doesn't get to pick. On the contrary, the other person will have to pick her. My second concern is reproduction following marriage. If the other person wants to have kids, it won't work for us, because we don't want to pass on her disability. I am getting old, and if she wants to reproduce, I won't be able to help her should she run into any difficulties. And that will be doing her a disservice. We don't want her to find a guy, bring him home and have a kid with him. We are 
not that kind of family, because I think long term. And everything is predestined. If she meets a good guy whose parents or siblings do not have any apparent disabilities and whose parents are loving-I have an elder daughter, after all, and once we pass away, she can look out for Y-then she won't have to worry about the rest of her life.

She feels bad about herself sometimes, thinking that she is poorly educated and therefore won't get to date or have kids. I told her not to even think about having kids, because people without disabilities won't settle for her unless they have special reasons. And I named two possible reasons. One, the guy is a widower with one or two kids, so he will only need Y for companionship and not for childbearing. Two, the guy has a disability himself, and his family doesn't care who he marries as long as no kids are planned. And the second reason is more plausible. So she feels awful in her heart. Sometimes she will wonder if she can find a good-looking guy, and I will tell her that the two of them will have different things to think about and move in different circles without ever converging.

$\mathrm{Q}$ : Did any doctor advise against $\mathrm{Y}$ having kids, or are you worried about who is going to take care of the kids?

Y's mother: Here's the deal with me and her dad, and it's actually something private we keep in the family. We don't know whose gene is at fault. We never had any kids before we got married, and after Y was born, I felt helpless and hopeless, but I didn't despair like some other people.

The daughter of my elder brother got married and had her amniotic fluid tested 3 months into her pregnancy. The test showed Down syndrome, so she had an abortion and divorced afterwards. Whether it is the gene on my side of the family or other reasons, I don't want to find out.

I also have a distant relative. Well, not exactly too distant. It's my aunt, my dad's younger sister. Her son was in a truck on a hill, the truck rolled over and he rolled down the hill and sustained injuries to his head. So he will blabber sometimes. Then he got married and had a daughter, who looks a little like she has Down syndrome, but she functions well. I just can't pinpoint it. Her dad plans to have the future son-in-law live with them, and I asked her mom if she is mentally prepared, because disability is no joking matter. Having a kid is not just to reproduce, because life itself doesn't mean much. Once you die, you don't know what happens next, but if you are not well prepared, you will have ruined the lives of the next generation. They live in the countryside of Changzhou, not in Shanghai like we do.

All things considered, I really don't see the need for $\mathrm{Y}$ to have kids. If you like pets, you can adopt one or pay to see one. Even tigers can be adopted in name. As for people, if you like kids, just go see some instead of having them as your personal possession, because you will have to consider whether you have the ability to raise them. We are approaching 60, so who will help raise kids for Y? She can handle eating, shopping and laundry. But if she wants kids, who is going to educate them? We won't be able to do that. It's not about reputation or looking good. We don't need any of that, because we are very realistic. Actress Qin Yi has a son and a daughter. The son had a high fever when he was 16 and suffered cerebral palsy as a result. She is a celebrity, and even celebrities have to deal with disabilities. 
What I am thinking is this: maybe fate will have it that she will meet a guy whose disability isn't that severe, and that the two of them can manage to live together. That will be okay with me. Having kids could be a trap. When you have a dog or a cat, you can give it away, but not kids, because they are a higher form of life. There's no way around that, so I have to be extra careful. I have a kid with a disability, and to let her have her own kids is unnecessary and I need to think it through. I just want her to be happy. She can be with a guy who can help her get on the Internet to communicate with grown-ups, and that should be good enough. They don't need to do anything fancy. In the news, wasn't there someone who has cerebral palsy but became a musician later, a conductor actually? But it takes effort. I didn't make the effort, and I couldn't have made the effort.

We had a meeting with a teacher, and one of the parents asked whether a platform could be provided for kids like Y so that they could get together often. They are maturing in age and some of them are already in their twenties and thirties. They might be able to pair up without planning to have kids. I liked that suggestion, because they will have desires once they reach a certain age. Y understands the desires. But kids cannot be in the picture. There's something wrong with the genes, so it's unnecessary to create something bad and try to remedy it afterwards. But who can I talk to about this, Shanghai Disabled Persons' Federation (DPF)? I feel bad about a lot of people with severe disabilities and really miserable family lives. Looking at them, I know I am luckier. There's this family with twins. Both have disabilities, are in bad shape and getting on in age. Their parents literally gave it their all. They were asked to help with the oral history book of yours, but they don't want to look back. We are all taking one step at a time. I feel that I should cooperate with you, because I want to talk about my family with you guys. I can't exactly talk to my neighbors or co-workers. But with those who know people like us and who are in the loop, I can talk about what I think.

Q: Do you keep in contact with organizations such as Shanghai DPF and the Sunshine Home?

Y's mother: The Sunshine Home hosts arts and crafts activities and some of the participants are in their thirties or forties, have apparent disabilities and look like they are deteriorating right in front of your eyes. I won't let Y go there. Why? Because that place would drag her down. Sometimes our cell phones will get stuck and she will fix it for us. She might not be the best at it, but she can get it done. Yesterday I saw her chatting online and clicking away, with earphones on and the dog in her arms. I am happy to let her chat with her classmates like that. And I told her that she can even learn new Chinese characters just by typing more often online.

\section{Different Bonding Among Four Family Members}

\section{Q: How does your husband treat Y normally?}

Y's mother: My husband tries his best. He was basically the one dropping her off and picking her up at elementary school and the primary vocational school. I keep 
reminding Y to be grateful to her dad, and she is grateful. Sometimes when we see beggars on the street, she will tell me that she wants to give them money, and I will encourage her to do it since she has that thought herself. I tell her that now that she knows to be grateful, she can buy whatever she wants and I won't restrict her. My elder daughter is more self-centered and has no delicate feelings, not at all. I tell my elder daughter that she should show a little bit of gratitude.

Q: How does your husband feel about Y's condition?

Y's mother: We have never worried about our daughters, be it the adopted one or the biological one with the disability. Why? Because compared to other families who have kids with disabilities, we are in much better shape, which we are pleased about. Y has a job now, which is really nice. And I told my elder daughter to be independent and to look for a job herself. That's where things stand with us, and we have to face it no matter what.

Q: Y's elder sister was six when she was born. How does Y get along with her?

Y's mother: They have never really been able to play together. Y was born in the beginning of the year and her sister was born towards the end of the year, and they are 6 years apart. Her sister isn't very talkative at home either, and right now her life basically consists of work and home, plus getting on the Internet. She seldom interacts with us. I keep telling her sister, "Once we are gone, you will be Y's guardian and will have to take on the responsibilities. You see how I have been caring for both of you. When we get old, you should care for her the way I have been caring for you. That way I will be able to rest in peace when I am gone."

Q: So you hope that her sister can take care of her in the future, right?

Y's mother: That's not very likely. Only parents can give this kind of love, whereas everyone else will do it out of courtesy, (sobbing), really. I am not sure her sister is reliable. I am not badmouthing her behind her back, but she is kind of self-centered. I haven't talked about her at all so far, because she seldom interacts with us.

$\mathrm{Y}$ is very attached to home and hopes to see her sister at home. She will ask why her sister isn't coming back yet. She is very attached to her sister, but the feeling isn't reciprocated. That's why I say that as long as I am around, I will watch Y grow up little by little, year after year. Once I get close to not being able to see anything, I will have to do something about it.

We have a happy family. We joke around with each other and there's nothing we can't say amongst ourselves. Y says that I am the big boss at home and everyone should listen to me. She would like the four of us to just stay home to enjoy good food and have fun. But I tell her, "When you were going to school, you had summer vacations. I had poor health then, so I could often stay home. Now we must all work, because living standards are higher now. When you go out, you could spend close to 100 yuan on almost nothing."

Q: Are you and your husband under a lot of pressure taking care of two kids?

Y's mother: The pressure isn't financial. I am actually a very outgoing person, but I don't want to let too many people know about my daughters. That's why I moved, even though that's not the only reason I moved.

$\mathrm{Q}$ : When did you move? 
Y's mother: We moved several times, in 2000, 2003, 2004, and 2005. I wasn't making a special effort to move since there were no neighbors gossiping about me. Back then, apartments were cheap. I was in real estate and constantly flipping apartments. So financially, I have no problem raising two kids. The main issue is that my younger daughter has a disability and my elder daughter's registration for Shanghai residence was delayed.

Q: Why was it delayed?

Y's mother: The community director of women's affairs asked me where I had got my elder daughter. I said someone gave her up and I adopted her, but she didn't believe me. She thought I had picked up an abandoned baby. So she ignored my elder daughter's paperwork and didn't register her for Shanghai residence. I didn't think too much of it and believed that it was okay not to have residence. She was able to finish elementary school but ran into trouble in middle school. When she was in ninth grade, since she had no Shanghai residence, the school told me that she couldn't continue at the school. What could I do then but to take her home? For several years back then, I was in poor health and didn't have a stable job.

Then I figured that my elder daughter couldn't really do without Shanghai residence, so I made inquiries at a lot of government departments. Registering for residence was not as easy as you would have liked it to be. I had to start with the lowest department and work my way up, and had to submit all kinds of materials from the past. And I had moved to Putuo District, which complicated matters. Then I met someone several years older than I am. He wanted to help. My younger daughter has a disability, and I had developed rheumatoid arthritis after childbirth and other illnesses. He reviewed my materials and helped me. So what really happened was that thanks to the disability of my younger daughter, I was able to register my elder daughter for residence.

Q: Did your elder daughter continue schooling later?

Y's mother: After she graduated from middle school, I told her to skip high school and enroll in a college for grown-ups. I said, "Even though I wasn't able to register you for residence in time, I did succeed eventually, and now you are a Shanghai resident. You should thank your sister for the residence." She works in after-sales services at a website and makes 5,000 or 6,000 yuan per month which she thinks is enough for her. She is a Capricorn while $\mathrm{Y}$ is a Gemini. Gemini people are known to have unstable lives and go through dramatic life changes.

I am very proud now, because my two kids have paid jobs that come with health insurance and pension. If my elder daughter wants to open a small shop online, as long as she has a platform and money, I will let her do it. If she decides to be grateful and help her younger sister, that would be nice.

But what I am saying now is all irrelevant. My elder daughter will date and get married, and it would be a blessing if she doesn't come to bother us at home after that. She is an average person, and once she is married, she will have an average family and there won't be anything spectacular expected of her. So what hope will there be for me? Do I really think she will turn around and take care of her younger sister? 
I used to ask the teacher from Qixing School to take care of Y for me when I get old. But the teacher has been seeing doctors over the past 2 years and is now 8 or 9 months pregnant. When we first left the school, she kept in close contact with us. But now that she is having her own baby, there will definitely be distance. So I've thought it all through. Y just needs several friends who will care about her, as well as some savings and a place to live, and that's about it for her in the future.

I may not necessarily appoint her sister as her guardian in the future. She is 20 now. As she grows older, I will teach her about money. For example, the way savings work is that I put aside 100 yuan and will get 105 yuan a year later. She will need to learn to read the forms and to seek the bank manager's help with understanding the details. I haven't started teaching her any of that yet. I want to wait till she is older and can use her brain better. She knows how to buy things online using Alipay. For example, a bottle of water costs 2 yuan, the card has 2,000 yuan to begin with and will have 1,998 yuan left after she has bought the water. Alipay will immediately calculate this for her because she won't be able to do it herself. She still has no clear concept of how much change she should get back if she uses 100 yuan to buy something.

Q: So she isn't very good with calculations?

Y's mother: She can do simple ones like getting 95 yuan in change back after using 100 yuan to buy something costing 5 yuan. But she has no clue when you further break it down into cents. She likes to buy drinks from Lawson and FamilyMart, and 100 yuan seems to be nothing to her because she doesn't bother to count the change. When she goes to Huxi Cultural Club in Putuo District, she will often buy some trinkets to hang on her cell phone, and the ladies selling those things there really like her. One time she even bought some clothes there and I asked her how on earth she could wear those clothes out, and since we couldn't exactly return them, she is not allowed to buy them anymore. If I really get mad at her, she will burst out crying.

Q: Does she still buy them?

Y's mother: She does, because she just can't help it. Even if she brings coffee from home, she will buy coffee. She asks me why she can't manage to save money, and I ask her how much she spends and how much she makes each month. She is mindless about that and only knows to ask me for more once she has spent all her money. But she is sweet in that when I talked about buying a new fridge, she offered all the money she had.

Q: Does she have any idea about saving money now?

Y's mother: She does. She has a lot of ideas. I told her she must save money.

$\mathrm{Q}$ : Was Y close to her grandparents?

Y's mother: Not really, since she has never spent much time with them.

Q: Does Y socialize with relatives, like cousins?

Y's mother: They hardly communicate. If asked simple questions like where she works, when she goes to work, what she does at home, and whether her job is tough, she can engage in some communication. But she will never strike up any conversations with anyone. 


\section{Grateful for the Help Received}

Q: Over the years, have you ever felt that the walls were closing in on you?

Y's mother: The walls closing in on me? Not really, because she had always received compliments and honors at school. She participated in every activity at school and won a lot of honor certificates and trophies. No teacher has ever called to complain about her, that's just unthinkable. I feel that she has always been in a very comfortable environment, so there's no need for pain or low self-esteem.

Q: Are you still busy now that you have retired?

Y's mother: The year before last, I took over a street booth selling books and newspapers. I did it for her, because I had wanted her to run it with me. She tried for a while, but it didn't work out, because she had to handle money and she was totally clueless. So I didn't want her to continue because it wasn't the right job for her. I was brainstorming for her. If we opened a clothing shop, she might not have the ability to run it and I might not have it either. When it was time to sign her contract with Papa John's, she didn't want to sign it. She wanted to work with me instead doing whatever I ended up doing. But working with me is risky, and what about the future when she has no pension? Years will go by and government policies might change. Besides, I am getting old, and if she follows whatever I do, what will happen to her if I get really sick one day?

As for that booth selling books and newspapers, Y can't run it and I have no time, so I got a person with ID to watch it for me, like opening and closing it. I used to pay him 300 yuan. But as I got busy with things at home, I decided to pay him 1,000 yuan per month to be in charge of the booth, and I will just drop by every Friday afternoon to organize the newspapers. This guy is in his fifties, with ID and something wrong with his eyes. He used to collect garbage for a living, and is very grateful for the help I am giving him. I have always been saying that I want to give back, because I have received a lot of help from society, without which it would have been difficult for my elder daughter to register for residence and my younger one to go to school or get a job. I am really grateful.

Q: On the phone, you mentioned that you really admire Mom Caihong. ${ }^{3}$ What do you admire about her?

Y's mother: Right, I watched her giving a talk during the news section of the program New-Age Uncle, but I don't know where her studio is and can't find a good address online. Her kid has a more severe disability than mine and is even less able, but she has never given up. A lot of kids with cerebral palsy can gradually make progress if the grown-ups try hard and train them patiently. That's why I say that it's not easy to be a mom. And she set up that studio and hired a lot of employees, including parents from different places. I would like to find her platform and to

\footnotetext{
${ }^{3}$ Mom Caihong: Caihong Zhang is the mom of autistic child Weijia Zhang. For many years, she has been actively sharing her experiences with parents of other autistic kids and providing mental support. She self-funded and set up a Mom Caihong's Studio in Minhang District, Shanghai, where she has established a platform for intervention education and experience sharing for autistic children. She is known as "Mom Caihong.".
} 
donate my time working there while learning how I can help Y make friends so that she can have a wider social circle.

Q: Do you have any expectations for society and the government? And expectations for the future?

Y's mother: I hope that the government and society will give more attention and show more care to people with disabilities, and as parents, we will be grateful.

\section{Interview with Y's Co-Worker (I)}

Interviewee: Ms. A (manager of the restaurant)

Interviewer and writer: Liting Mo

Interview date: January 23, 2018

Interview place: Restaurant where Y works

Q: What's your position at the store?

A: I am the manager.

Q: $\mathrm{Y}$ is an employee being cared for. How many employees being cared for in total does the store have?

A: $\mathrm{Y}$ is the only one. At the other store that I manage, there are three employees being cared for.

Q: When did Y start working here? How long has she been with you?

A: I have been here for 1 year, and $Y$ has been here for 2 years.

Q: What's Y's work schedule like?

A: She works from 11 a.m. to 8 p.m., with a break from 1 to 2 p.m. That's a total of $8 \mathrm{~h}$.

Q: What exactly does she do?

A: She is pretty skillful at making pizzas and appetizers, even though sometimes she needs to be reminded of what the next step is. She knows what she is doing, and is easier to manage than a lot of people now in their twenties. We won't let her near windows where pizzas and other food are handed out, because we worry that she might get burned, being a little different as she is. It has been tough teaching her, but then, it takes even people without disabilities a long time to learn. She mainly had her own mentor, an older female employee, teaching her.

Q: Has Y ever been late for work or left early?

A: No, she doesn't come late or leave early. She is normally very punctual.

$\mathrm{Q}$ : Compared to when you first started working here, have there been any changes or improvements in her work? Or has she always been the same?

A: I haven't really seen any changes. A lot of employees get emotional sometimes. She does too, not as often, and doesn't stay agitated for long. You will have to speak to her first. She will never speak to you unless spoken to. She just does what she needs to do quietly.

Q: I saw a lot of orders coming in during lunch hour. Do you rush her when it gets busy? 
A: We do, occasionally. We will just say, "Y, hurry up." And she will acknowledge it. When it gets busy, everyone gets rushed. And we need to communicate across the workstations, otherwise we won't be able to get anything done. The ovens and drinks station have to be always manned, so communication is essential. Y has worked for a while, so she gets it by just watching. She knows all the processes, like when she puts something in the oven and there's no one watching the oven, she needs to summon the on-duty manager or a partner saying that she has something in the oven.

Q: Will she say that without anyone prompting her?

A: She will, but very seldom. Normally it will be us telling her, "Y, you are on your own now. Watch out for my food, and call me when it's done," or "I am not going to be at this station, I have to get something done at another station." Once we tell her, she will remind us.

Q: Do you treat employees being cared for and regular ones differently?

A: I do. But we have the same requirements for everyone when it comes to quality, including food portions, ingredients, and sizes. Employees being cared for are not supposed to do anything randomly, because there's only one set of standards. If it has to be $200 \mathrm{~g}$, it has to be $200 \mathrm{~g}$. We will teach Y the standards making sure that she strictly follows them. But in other areas, we will take it easier on her.

Q: In which areas will you take it easier on her?

A: Cleaning up, for example. We are supposed to clean up our own workstations. She will forget. She will have finished making something but not put the ingredients and tools back. On those occasions, we will remind her.

Q: Do you recall when you scolded her or when you praised her?

A: When we got busy and she made mistakes, I would scold her, "Come on, Y, you did this wrong. I told you otherwise." When we are busy, we don't watch what we say to each other, and that includes me, on-duty managers, and others who report to me. But then, we don't dwell on it afterwards. When you get busy, things happen.

$\mathrm{Q}$ : So she has adapted to the environment at the store?

A: Right, she knows my temper and habits, and knows the tempers of other employees. And sometimes she will reply, "Okay, Manager, I got it." That's where communication pays off.

Q: When will you praise her?

A: For example, when she finishes something fast or does a beautiful job with something. She has her strengths, and sometimes she outperforms people like us without disabilities.

Q: I watched her work in the morning. Even though she is slow-paced, she doesn't make mistakes, right?

A: Right. She is clear-headed and knows what to do next. But she makes mistakes when we get busy. Well, people without disabilities make mistakes, too. Then we will tell her, "We might rush you when we get busy, but don't feel pressured. Just speed up a little bit." And she will listen.

Q: Did anything happen with Y that really impressed you?

A: I don't come to this store often. I manage two stores and go to corporate meetings as well as the FDA. I come to this store once a week or once every 2 weeks.

$\mathrm{Q}$ : So you happened to be here today. 
A: There's a mentor here who is responsible for Y. You saw her just now, and she is the one who trained Y.

Q: So you manage another store, right? Can you tell us about the employees being cared for at that other store?

A: We have two, and sometimes three, employees being cared for there, and they are all very good. The parents are very nice, too. They are happy that their kids, being the way they are, have a job. And people like you often drop by to communicate and to check in on the kids, so the parents are really contented. Some of the kids actually have a more stable and better life than those without disabilities.

Q: Do Y's parents communicate with you?

A: Her mom often communicates with our assistant manager. Our assistant manager is the shift manager who communicates with parents. Some parents might want time off for the kids, or the kids might have other engagements sometimes, so the parents will talk to the shift manager. The shift manager is actually in a social media group with the parents of employees being cared for, and she will announce in the group, "Let me know if something comes up. Otherwise I will just assign the kids the usual shifts."

Q: So the shifts are assigned every week? Do employees being cared for work 5 days a week with 2 days off?

A: Right. Five days a week with 2 days off, that will never change. But the days off may not always be the same days. We are located in a business building here and not busy on Saturday or Sunday. At my other store, I have two male employees being cared for who live close to the store, and the parents are very supportive of their working more hours. So I will ask them to work OT whenever there's the need. We treat everyone the same.

Q: Y works in the kitchen. Does she ever interact with customers?

A: She doesn't, because she is an introvert.

Q: Does she interact with co-workers or with you?

A: Not a lot, but she will talk if you talk to her. If you don't approach her, she won't talk, but she will greet you, nod her head and smile, and that will be it.

Q: You see her at work, but are you in contact with her in private?

A: Hardly ever. But we have a townhall every week, or the on-duty manager will report to me when he sees something off with someone and then we will talk it over with that person. There might be friction at the store or between co-workers, or something happening at home, so we need to observe what the employees are thinking about, as if we were their parents. I put myself in their shoes for them to have a sense of belonging, and for everyone to get along harmoniously at work. We have annual meetings, but Y's mother thought the venue was too far and didn't let Y go with us.

Q: Overall, what kind of employee is Y?

A: She knows what she is doing, does what she is supposed to do, and is punctual. 


\section{Interview with Y's Co-Worker (II)}

Interviewee: Ms. B (on-duty manager of the restaurant)

Interviewer and writer: Liting Mo

Interview date: January 23, 2018

Interview place: Restaurant where Y works

Q: What do you normally do at the store?

B: I go wherever the action is. You saw just now that it got busy in the kitchen, so I was handing out food there. Now I am filling in for the cashier in the dining area.

Q: How long have you been interacting with Y?

B: She has always had that mentor in the kitchen. I haven't been interacting with her for that long.

Q: Do you usually communicate with Y? Do you see any changes in her compared with when you first met her?

B: I do, the changes are pretty apparent. When I first came here, I figured that since I am the same generation as Y, I went out of my way to talk to her, only to have her nod her head or smile, so I felt rejected. But then co-workers in the kitchen told me that $\mathrm{Y}$ is a little autistic, and I got it. Now I know just the right way to talk to her, and she will help me arrange set meals. Sometimes when it gets busy, she will even boss me around, "I told you to take over for me here." And people around us will joke, "This girl can boss us around now." (Laughing loudly)

Q: Do you communicate with Y after work?

B: Hardly ever.

Q: Are you two connected on WeChat? Do you talk on WeChat?

B: We are connected, but we seldom talk. We normally assign shifts once a week, and I will just send the weekly schedule to her. If something comes up, she will tell me and I will adjust the schedule. Other than that, we don't talk.

\section{Interview with Y's Co-Worker (III)}

Interviewee: Ms. C

Interviewer and writer: Liting Mo

Interview date: January 23, 2018

Interview place: Restaurant where Y works

Q: How are you? I just want to get some idea today of how $\mathrm{Y}$ is doing at the store. What do you do at the store?

C: I work in the kitchen and help wherever it gets busy.

Q: How long have you been with Y?

C: About 2 years, ever since she joined the store.

Q: So you have been training her the whole time, right?

$\mathrm{C}$ : Right. I was the one who taught her how to make pizzas. 
Q: Can you tell us the processes when $\mathrm{Y}$ was learning to make pizzas?

C: So I would teach her to knead and toss the dough first. After she had learnt to do it the standardized way, I taught her how to add the ingredients. And that's how I taught her to make all kinds of pizzas.

Q: What does Y mainly do in the kitchen?

C: She mainly kneads and tosses dough and makes pizzas. Kneading and tossing dough is the most tiring job, and if we get super busy, I will stop her from doing that and have her make appetizers instead.

Q: And making appetizers is relatively...

C: It's the easiest job, as you basically just pick things up with your hands. If chicken wings are ordered, you just bake chicken wings. Kneading and tossing dough is very tiring because that station has to be constantly manned, but the ovens are too hot and I don't want her to get burned.

Q: At work, does she arrange for herself what to do first and what to do next, or do you arrange it for her?

C: I will arrange for her and remind her, otherwise she won't follow the right order.

Q: What do you mean by not following the right order?

C: For example, we won't let her make drinks. And I will have to send her to make appetizers or make dough, otherwise she will just stay put at one workstation and we will be behind with the food.

Q: When you are behind, will you rush her?

C: I will for sure. When we are behind, I will say, "Girl, can you please hurry up?" and she will do as I say. So all is good.

$\mathrm{Q}$ : What do you think is the biggest difference between when she first came and now?

C: When she first came, she was quite a handful. Nobody knew what to do when we first came here, and I was no exception. The first day she came here, she had just left her school and parted ways with her classmates, and she found herself in a strange place. For 3 months, I felt I was going out of my mind training her. And it took me three whole months to teach her all the processes, but now she knows how to make everything including dough, appetizers, noodles, and rice. The hardest thing during the first month was teaching her to knead and toss dough, because whenever she messed up, she would turn her head and burst out crying. There was one day when she cried five times.

Q: What did you do when she cried?

C: I was so flustered when she cried. I had to comfort her, because she is a little different from us, after all. And at the end of the day, being a mom myself, if my own kid cries in a workplace, I would want her to be comforted.

Q: Is it still not easy working with her?

C: It's not so bad now. As long as I arrange everything ahead of time, Y will get it done.

Q: Do you communicate with her when you are not busy with work?

C: I do. I will tell her, "If you don't talk to me, I will keep you here to work for free." And she will say, "Okay." 
Q: So you do chat with her.

C: I do. We will have time to ourselves between 3 and 5 p.m. when there are no orders. Then she can sit there and have a rest, and I won't give her any work. When it's time for my own lunch break, ${ }^{4}$ I will arrange some work for her. I used to not let her touch knives since they are sharp, but now she wants to do more, so I will slowly teach her more. She can get everything done really well. As long as you tell her what to do, she will do a good job.

Q: What do you chat with Y about?

C: Just small talk, like how her mom is doing and how everything is going at home. Sometimes I will ask her about her age and whether she has a boyfriend. It doesn't hurt to chat with her. As soon as she opens up psychologically, she will talk to you more.

Q: So is she willing to communicate with everyone now?

C: She won't take the initiative to do it. The exception is that when she is making food and cannot find something or doesn't know what to do next, she will come and ask.

Q: Do you see any difference between her and regular employees?

C: Actually, it's like what her mom said, she is slightly autistic. In terms of intelligence, she is a very smart girl and not like the kind of employees being cared for we normally imagine... she just doesn't like to communicate with others and doesn't like to talk.

Q: Did anything happen with her that was memorable for you?

C: Not exactly. Maybe sometimes when she made mistakes and I got mad at her.

Q: Do you still do that now?

C: Not now. She will go back and tell her mom that I have been really mean.

Q: What do you think of her self-discipline? And do you treat her differently from other employees?

C: She is good at self-discipline, and I treat her exactly the same as I treat other employees. Psychologically she is a little different, but since she works here, I told her, "Y, you are the same as everyone else. You have been here for 2 years, and if you make mistakes, you will hear about it from me, like everyone else." She knows that.

Q: Do you talk to her on WeChat?

C: Only occasionally, because I don't like talking on WeChat. (Laughing loudly)

Q: Are you connected with her mom on WeChat?

C: I am. Her mom is very busy, so we only talk occasionally. I am very busy myself and don't really have time for chatting.

Q: Does the store organize any group activities?

C: It does, like group dinner on New Year's Eve. We invited her along, but her mom wouldn't let her go. It wasn't at our store and her mom was worried.

\footnotetext{
${ }^{4}$ Employees at the store eat and take breaks at different times.
} 


\section{Interview with Ms. Y}

Interviewee: Ms. Y

Interviewer and writer: Liting Mo

Interview date: January 23, 2018

Interview place: Restaurant where Y works

(Y was a little nervous.)

Q: Let's look back on when you were going to school. Do you still remember elementary school?

Y: When I was young, I was bullied all the time at preschool.

Q: How were you bullied? It's okay if you don't remember.

Y: Nobody would play with me.

Q: I see. You attended Qixing Special Education School for a while. Do you remember what you learned there?

Y: Dancing and singing.

Q: That's nice. Were there any organized performances? Did you perform outside school?

Y: I did.

Q: What kind of performances were you in?

Y: My dance teacher, Ms. Fu, was very nice.

$\mathrm{Q}$ : Can you tell me how nice she was?

Y: She would teach you one on one.

Q: What kind of dance did you do?

Y: Gymnastics. She took her job seriously.

Q: How many kids were in this gymnastics dance group?

Y: More than ten.

Q: And Ms. Fu taught each of you one on one?

Y: Right, because some took longer to learn than I did.

Q: So you picked it up faster. Are you still in contact with Ms. Fu?

Y: I was when I first graduated. Then I lost contact with her.

Q: Are you still in contact with other teachers or classmates from the special education school?

Y: I am.

Q: Can you give me an example?

Y: I keep in touch with this girl.

Q: What do you two talk about?

(Silent)

Q: Do you go out together?

Y: We do.

Q: How did you get to the special education school from where you lived? Was it far?

Y: Not far, and I took the bus.

Q: So your parents didn't drop you off at school?

Y: They just dropped me off at the bus station. 
Q: You were pretty independent then.

Y (hesitating): My parents dropped me off for the first 3 years... then I went to school on my own when I was in seventh or eighth grade.

Q: How long did you stay at Changning Primary Vocational School?

Y: Three years.

Q: Do you remember what you learned there?

Y: There was a teacher, Mr. Xia, who taught making pastries. (A long pause) And another teacher, Mr. Tong, who taught meeting logistics. (Another long pause) I tested for certificates.

Q: What certificates did you test for?

Y: Meeting logistics and making pastries.

Q: You must have been so good. Were the tests hard?

Y: I had to memorize a lot of stuff. I hadn't been too serious about it.

Q: What else did you learn at the vocational school?

Y: Dancing, but the teacher wasn't as good as Ms. Fu.

Q: Are you still in contact with classmates or teachers from the vocational school?

Y: Ah... I was when I first graduated, then I didn't keep up. Only for Teachers' Day.

Q: Teachers' Day?

Y: I sent cards for Teachers' Day. For the first several months after I graduated, I just wanted to bring gifts to the teachers, and flowers.

Q: That's nice. Did the vocational school organize any activities? Activities for everyone to participate in?

Y: We went out together.

Q: To do what?

Y: To dance.

Q: Where did you go for that?

Y: We danced to English songs.

Q: Besides dancing, what other group activities has the school organized?

Y: The school took us to the movies.

Q: What else?

Y: It also organized field trips.

Q: Where did you go for the field trips?

Y: We visited... (couldn't remember) and we went to movie locations.

Q: Oh, you probably went to the Chedun movie location in Shanghai. How did you go to the vocational school from where you lived?

Y: I took the bus, too.

Q: Was the school far?

Y: Not far by bus.

Q: Let's talk about what a day is like for you. When do you get up?

Y: Nine a.m.

Q: What do you do for breakfast?

Y: My parents make it at home.

Q: When do you normally leave for work?

Y: I take the bus. 
Q: When do you usually get to the store?

Y: Forty-five minutes.

Q: Right, you got to the store today at 10:45 a.m. Were you ever late?

Y: Occasionally.

Q: I see. Can you tell me what you do here at the store?

Y: I work in the kitchen. (Head lowered and speaking in a very gentle voice.)

Q: What do you do for a whole day's work? For example, what do you do in the morning? And what do you do in the afternoon?

Y: I have lunch at 1 p.m., and I go back to work at 2 p.m.

Q: Do you bring your own lunch or does the store provide lunch?

Y: I bring lunch.

Q: Do you make the lunch yourself?

Y: My mom makes it.

Q: I saw that you spent the whole morning making dough. What else do you do besides making dough?

Y: I clean up... if there's nothing else to do.

Q: Do you get busy in the afternoon?

Y: Between 4 and 5 p.m., 5 and 6 p.m.

$\mathrm{Q}:$ Oh, so those are the busiest hours?

Y: We get busiest between 6 and 7 p.m.

Q: When do you get off work in the evening? Where do you go for dinner?

Y: I go straight home and my parents will have dinner waiting.

Q: When do you normally get home?

Y: Around 8:40 p.m.

Q: Besides making pizzas, do you make appetizers, too?

Y: I do that sometimes.

Q: On your own, you can make a pizza from beginning to end now, right?

Y: Right, but if I have a lot to make, she (the mentor) may have to help me.

Q: Can you tell me how you learned to do it all? You do it so well and are so skillful.

Y: I didn't know anything at the beginning, then I learned slowly... (speaking in an increasingly gentle voice.)

Q: Can you take some time to think about it and tell me more?

Y: The mentor trained me.

Q: How did the mentor train you?

Y: She would do it, and I would copy what she did. Again and again.

Q: How long did it take for you to learn?

Y: About 3 or 4 weeks.

Q: Do you talk to the mentor?

Y: I do... (voice trailing off)

Q: How long have you worked here?

Y: The first year was an internship, this is the second year.

Q: So you are in your second year here. You are doing great.

Q: Do you normally chat with your co-workers at Papa John's?

Y: Occasionally. 
Q: Who do you chat with most often?

Y: I don't chat often. (Head lowered and speaking in a gentle voice.)

$\mathrm{Q}$ : Can I ask you whether the mentor or the manager has ever scolded you?

Y: Not really, they are okay... (speaking quietly as if not inclined to talk.)

Q: You work here now. Does the store organize any activities for everyone to participate in?

Y: No.

(Twenty minutes later, after Y had lunch in the employees' break room.)

Q: Let's talk about what you do when you have time off and when you get home.

Y: I just watch TV and my phone.

Q: Do you get on WeChat?

Y: I do.

Q: Who do you usually chat with?

Y: Friends.

Q: Oh, like who?

Y: From Changning.

Q: You mean friends from Changning Vocational School?

Y: Right, but we don't chat a lot.

Q: What do you normally chat about?

Y: If I want to go out some day, I will just tell her. (Speaking in a gentle voice.)

Q: When you get home, do you talk to your elder sister?

Y: Not really... I talk a lot to my mom, but not so much to my sister or my dad...

Q: I see. Which days of the week do you usually have off?

Y: I work 5 days with 2 days off, and it depends which 2 days I have off.

Q: What do you do on your days off?

Y: Me? (A long pause) If someone wants to go out with me, I will go. Otherwise...

Q: Who will ask to go out with you?

Y: Friends.

Q: Where did you meet the friends?

Y: At Changning (Vocational School).

Q: What do you usually go and do?

Y: Movies, or to eat out.

Q: Which movies?

Y: Worry-Free... (Voice trailing off, trying to recall.)

Q: Was it Worry-free Convenience Store? Starring Jackie Chan?

Y: Right.

Q: Do you go out for fun with your family?

Y: I do. We go shopping.

Q: That's nice.

Y: We also walk the dog.

Q: You are very loving. You like having dogs, right?

Y: Right.

Q: What kind of dog? And how old is it?

Y: A poodle. (Silent)

Q: Who takes care of the dog? 
Y: We all do. When I get home, I will take care of it.

Q: Why do you like dogs?

Y: I just do. Do you play Jump Jump?

$\mathrm{Q}:$ Me? I do. What's your score?

Y: I can score 200.

Q: That's awesome.

Y: Last week I scored 280.

Q: Do your friends play that?

Y: They do, but they are not as good as I am...

Q: What else do you play besides that?

Y: I just read some random e-books.

Q: What kind of books do you like to read?

Y: (Silent)

Q: Tomorrow is a day off. Will you go anywhere?

Y: I will, with an elder sister.

Q: You mean your own sister?

Y: A girl from Changning Vocational School, who is older than I am.

Q: Do you need to get back to work now? (It was about 1:50 p.m.)

Y: I do. Bye.

\section{Observation of $\mathrm{Y}$ at Work}

Observation date: 10:30-20:00, January 23, 2018

Observation place: Restaurant where Y works

Observer and writer: Liting Mo

\begin{tabular}{l|l|l}
\hline Time & What Y did & Remarks \\
\hline $10: 30$ & $\begin{array}{l}\text { Y hasn't arrived yet, and the store is } \\
\text { setting up for the day ahead }\end{array}$ & The observer arrived at the store \\
\hline $10: 50$ & $\begin{array}{l}\text { Y entered the work area and changed } \\
\text { into work clothes }\end{array}$ & \\
\hline $11: 03$ & $\begin{array}{l}\text { After a customer placed an order, } \mathrm{Y} \\
\text { and the mentor worked together to } \\
\text { make a supersized pizza }\end{array}$ & \\
\hline $11: 05$ & $\begin{array}{l}\text { The mentor told Y which ingredients } \\
\text { to refill for the day }\end{array}$ & $\begin{array}{l}\text { When reminded by the mentor about } \\
\text { something, Y just gave simple replies }\end{array}$ \\
\hline $11: 09$ & $\begin{array}{l}\text { Handed out mushroom soup in the } \\
\text { kitchen }\end{array}$ & The store manager reminded Y of it \\
\hline $11: 10-11: 15$ & $\begin{array}{l}\text { Walked around to clean up and } \\
\text { organize. Went to the freezer in the } \\
\text { back of the kitchen to fetch something }\end{array}$ & \\
\hline
\end{tabular}


(continued)

\begin{tabular}{|c|c|c|}
\hline Time & What Y did & Remarks \\
\hline 11:18 & $\begin{array}{l}\text { Worked independently to complete a } \\
\text { takeout order for two pizzas }\end{array}$ & \\
\hline $11: 23-11: 45$ & $\begin{array}{l}\text { Received takeout orders and worked } \\
\text { independently to make five large-size } \\
\text { pizzas, one small-size pizza, and } \\
\text { breadsticks }\end{array}$ & $\begin{array}{l}\text { From time to time, } Y \text { checked the } \\
\text { food she was making against } \\
\text { specifications in the takeout orders }\end{array}$ \\
\hline 11:45 & Organized the pizza counter & $\begin{array}{l}\text { The mentor was talking to the regional } \\
\text { manager in the kitchen. Y kept to } \\
\text { herself }\end{array}$ \\
\hline 11:46 & $\begin{array}{l}\text { Received takeout orders and worked } \\
\text { independently to make three pizzas }\end{array}$ & $\begin{array}{l}\text { Y organized the flour on the pizza } \\
\text { counter. Female co-workers were } \\
\text { talking in the kitchen and Y kept to } \\
\text { herself }\end{array}$ \\
\hline 11:50-12:03 & $\begin{array}{l}\text { Worked independently to make three } \\
\text { pizzas and organized the pizza counter }\end{array}$ & $\begin{array}{l}\text { Eleven customers arrived at the store } \\
\text { and more takeout orders came in. } \\
\text { Everyone in the kitchen, including Y, } \\
\text { got busy }\end{array}$ \\
\hline 12:05 & $\begin{array}{l}\text { As customers kept arriving, Y received } \\
\text { instructions to make pizzas for dine-in }\end{array}$ & \\
\hline 12:10 & $\begin{array}{l}\text { Worked independently and in an } \\
\text { orderly manner to make five pizzas for } \\
\text { customers to take away }\end{array}$ & $\begin{array}{l}\text { Y noticed that ingredients were } \\
\text { running low and refilled them from } \\
\text { storage boxes }\end{array}$ \\
\hline $12: 10-12: 25$ & $\begin{array}{l}\text { Made pizzas at the counter, cleaned up } \\
\text { flour on the counter, and refilled } \\
\text { ingredients }\end{array}$ & $\begin{array}{l}\text { More customers arrived and occupied } \\
\text { eight tables }\end{array}$ \\
\hline $12: 25$ & Made two orders of breadsticks & The mentor helped \\
\hline $12: 25-12: 34$ & $\begin{array}{l}\text { Made pizzas of different sizes and } \\
\text { flavors }\end{array}$ & $\begin{array}{l}\text { Because there were more orders, the } \\
\text { mentor helped add the ingredients, } \\
\text { reminded Y what to do next, and } \\
\text { confirmed how many more pizzas } \\
\text { were needed }\end{array}$ \\
\hline $12: 35$ & $\begin{array}{l}\text { Organized and wiped down the pizza } \\
\text { counter }\end{array}$ & \\
\hline $12: 39$ & $\begin{array}{l}\text { After the orders were completed, Y } \\
\text { cleaned up the pizza counter, rolling } \\
\text { knives, pizza nets and baskets, put } \\
\text { away the ingredients and washed her } \\
\text { hands }\end{array}$ & \\
\hline $12: 45$ & $\begin{array}{l}\text { Worked with the mentor to organize } \\
\text { the flour cart }\end{array}$ & \\
\hline $12: 51$ & $\begin{array}{l}\text { Drank water at the pizza counter and } \\
\text { returned to the employees' break room }\end{array}$ & \\
\hline $12: 59$ & $\begin{array}{l}\text { Had a brief interview with the } \\
\text { observer }\end{array}$ & \\
\hline
\end{tabular}


(continued)

\begin{tabular}{|c|c|c|}
\hline Time & What Y did & Remarks \\
\hline 13:15-14:00 & $\begin{array}{l}\text { Rested and had lunch in the } \\
\text { employees' break room }\end{array}$ & \\
\hline 14:00-14:30 & $\begin{array}{l}\text { Helped chop vegetables and prepared } \\
\text { ingredients in the kitchen }\end{array}$ & $\begin{array}{l}\text { According to the mentor, Y } \\
\text { volunteered for the extra work }\end{array}$ \\
\hline $14: 41$ & $\begin{array}{l}\text { Made pizzas according to orders and } \\
\text { prepared ingredients by chopping } \\
\text { peppers and tomatoes }\end{array}$ & \\
\hline 15:11 & $\begin{array}{l}\text { The delivery person arrived at the } \\
\text { store for the takeout orders. Y stayed } \\
\text { in the kitchen by herself to organize } \\
\text { the orders before handing them to the } \\
\text { delivery person }\end{array}$ & $\begin{array}{l}\text { The on-duty manager helped Y pack } \\
\text { the takeout orders }\end{array}$ \\
\hline $15: 20$ & $\begin{array}{l}\text { The delivery person rushed order No. } \\
15 . \text { Y took the order and made pizzas }\end{array}$ & $\begin{array}{l}\text { The on-duty manager helped Y pack } \\
\text { the takeout order }\end{array}$ \\
\hline $15: 23$ & $\begin{array}{l}\text { Washed hands, organized ingredients, } \\
\text { and cleaned the hole-puncher and } \\
\text { pizza counter }\end{array}$ & \\
\hline $15: 30-15: 40$ & $\begin{array}{l}\text { Rested and played on her phone in the } \\
\text { break room }\end{array}$ & $\begin{array}{l}\text { Had some free time as there were no } \\
\text { takeout orders }\end{array}$ \\
\hline $15: 45$ & $\begin{array}{l}\text { Received takeout orders and worked } \\
\text { independently to make a supersized } \\
\text { cheese pizza }\end{array}$ & \\
\hline $15: 52$ & $\begin{array}{l}\text { The delivery person asked } \mathrm{Y} \text { how the } \\
\text { order was coming along }\end{array}$ & $\begin{array}{l}Y \text { was the only person in the work } \\
\text { area, so the delivery person sought } \\
\text { help from the on-duty manager for } \\
\text { communication }\end{array}$ \\
\hline 16:15 & $\begin{array}{l}\text { Had some free time as there were no } \\
\text { orders, played the WeChat game Jump } \\
\text { Jump }\end{array}$ & $\begin{array}{l}\text { The mentor set out spaghetti and other } \\
\text { food }\end{array}$ \\
\hline $16: 28$ & $\begin{array}{l}\text { The mentor asked } \mathrm{Y} \text { to organize the } \\
\text { bread cart and to set out food }\end{array}$ & \\
\hline $16: 56$ & $\begin{array}{l}\text { Received takeout orders, worked } \\
\text { independently to make four pizzas and } \\
\text { worked with the mentor to make two } \\
\text { orders of appetizers }\end{array}$ & $\begin{array}{l}\text { Nodded to the mentor and the } \\
\text { co-worker packing the takeout orders }\end{array}$ \\
\hline $17: 33$ & $\begin{array}{l}\text { Received takeout orders and made } \\
\text { pizzas and appetizers }\end{array}$ & \\
\hline $17: 46$ & $\begin{array}{l}\text { Cleaned the pizza counter and } \\
\text { pizza-making tools }\end{array}$ & \\
\hline 18:06 & $\begin{array}{l}\text { Received takeout orders, made pizzas } \\
\text { and helped pack the takeout orders }\end{array}$ & $\begin{array}{l}\text { Because it's tiring to make pizzas, the } \\
\text { mentor and Y took turns doing it }\end{array}$ \\
\hline 18:11 & Helped pack food & $\begin{array}{l}\text { Y talked to the delivery person about } \\
\text { order numbers }\end{array}$ \\
\hline
\end{tabular}


(continued)

\begin{tabular}{|c|c|c|}
\hline Time & What Y did & Remarks \\
\hline $18: 30$ & $\begin{array}{l}\text { Made pizzas and helped the mentor } \\
\text { make appetizers }\end{array}$ & $\begin{array}{l}\text { There were not many dine-in } \\
\text { customers. The majority were takeout } \\
\text { orders }\end{array}$ \\
\hline $18: 45$ & $\begin{array}{l}\text { Received a lot of takeout orders, made } \\
\text { pizzas and appetizers, and refilled } \\
\text { ingredients }\end{array}$ & $\begin{array}{l}\text { Y wiped down the pizza counter and } \\
\text { sink, and helped the mentor refill } \\
\text { ingredients. Because of the large } \\
\text { number of orders, Y made the pizza } \\
\text { dough while the mentor added the } \\
\text { ingredients }\end{array}$ \\
\hline 18:59 & $\begin{array}{l}\text { The mentor communicated with Y. Y } \\
\text { nodded her head and smiled to } \\
\text { acknowledge }\end{array}$ & \\
\hline 19:08 & $\begin{array}{l}\text { More orders came in. The mentor } \\
\text { helped Y knead and toss dough and } \\
\text { make pizzas }\end{array}$ & $\begin{array}{l}\text { The mentor asked } Y \text { why there was } \\
\text { dough on the counter for one more } \\
\text { pizza and } Y \text { said that she had made a } \\
\text { mistake }\end{array}$ \\
\hline 19:15 & $\begin{array}{l}\text { Received orders and worked } \\
\text { independently to make pizzas, and } \\
\text { cleaned up utensils in the work area in } \\
\text { between }\end{array}$ & $\begin{array}{l}\text { Female co-workers in the kitchen were } \\
\text { talking loudly and Y kept to herself }\end{array}$ \\
\hline 19:21 & Cleaned up & $\begin{array}{l}\text { The mentor asked } \mathrm{Y} \text { how the cleanup } \\
\text { was going, and } \mathrm{Y} \text { nodded }\end{array}$ \\
\hline $19: 45$ & Cleaned up & $\begin{array}{l}\text { Cleaned up the pizza counter and tools } \\
\text { like sieves }\end{array}$ \\
\hline 19:52 & Received orders and made pizzas & \\
\hline 20:00 & Cleaned up and got ready to leave & $\begin{array}{l}\text { The mentor reminded } Y \text { that she } \\
\text { hadn't cleaned up the work area }\end{array}$ \\
\hline
\end{tabular}

Translated by Cissy Zhao Edited by Andy Boreham and Zijian Chen

Open Access This chapter is licensed under the terms of the Creative Commons Attribution 4.0 International License (http://creativecommons.org/licenses/by/4.0/), which permits use, sharing, adaptation, distribution and reproduction in any medium or format, as long as you give appropriate credit to the original author(s) and the source, provide a link to the Creative Commons license and indicate if changes were made.

The images or other third party material in this chapter are included in the chapter's Creative Commons license, unless indicated otherwise in a credit line to the material. If material is not included in the chapter's Creative Commons license and your intended use is not permitted by statutory regulation or exceeds the permitted use, you will need to obtain permission directly from the copyright holder. 